\title{
ENDOSCOPIC SURGERY WITH A FLEXIBLE BRONCHOSCOPE AND ARGON PLASMA COAGULATION FOR TRACHEOBRONCHIAL TUMORS
}

\author{
Shinichiro Okada, MD, Hideyuki Yamauchi, MD, Shotaro Ishimori, MD, Shoichi Satoh, MD, Hiromitsu Sugawara, MD, and \\ Yoshiaki Tanaba, MD, Kamaishi, Iwate, Japan
}

\begin{abstract}
A variety of techniques have been used in an attempt to manage tracheobronchial tumors, such as bronchoscopic neodymium-yttrium-aluminum-garnet (Nd-YAG) laser, ${ }^{1}$ cryosurgery, ${ }^{2}$ brachytherapy, ${ }^{3}$ and electrosurgery with a fiberoptic bronchoscope and a snare. ${ }^{4}$ However, to date little information is available about argon plasma coagulation (APC) with a flexible bronchoscope in the treatment of endobronchial tumors. ${ }^{5}$ In this report, we describe the effectiveness and safety of the procedure.
\end{abstract}

Procedure. APC with a fiberoptic flexible bronchoscope was performed with general anesthesia administered with a laryngeal mask. ${ }^{6}$ The equipment included a high-frequency surgical unit (ICC350; Erbe, Tuebingen, Germany), a flexible bronchoscope (BF-1T30/BF-LT30; Olympus, Tokyo, Japan), and a flexible APC probe (APCP 20132-048/APCP 20132049; Erbe, Tuebingen, Germany). The argon flow rate was set at $2 \mathrm{~L} / \mathrm{min}$. The high-frequency unit delivered the high-frequency voltage required for ionization in the APC mode. Patients received hydroxyzine hydrochloride and atropine sulfate before the operation. Anesthesia was induced with propofol $(2.5-3.0 \mathrm{mg} / \mathrm{kg})$ and maintained with sevoflurane in $67 \%$ to $75 \%$ air. When necessary, a muscle relaxant such as vecuronium bromide was used. The flexible bronchoscope was passed through the slit of the cap of the swivel connector (Portex Catheter Mount; SIMS Portex Inc, Kent, United Kingdom), which connected the laryngeal mask and anesthesia machine, and it was introduced into the laryngeal mask tube and the trachea. The bronchoscopic maneuvers were performed without interruption of ventilation during the procedure. Percutaneous oxygen saturation with a pulse oximeter, blood pressure, and the electrocardiogram were monitored during the procedure. The APC probe was applied to the target lesion through the working channel of the flexible bronchoscope, and the necrotic specimen was retrieved with a grasping forceps.

Results were considered satisfactory when the aim of the procedure, such as curative resection, hemostasis, evaluation of the tumor, reduction of the tumor, and dilation of airway

From the Department of Thoracic Surgery and Medicine, Kamaishi Municipal Hospital, Kamaishi, Japan.

Received for publication March 23, 2000; accepted for publication June 14, 2000.

Address for reprints: Shinichiro Okada, MD, Department of Thoracic Surgery and Medicine, Kamaishi Municipal Hospital, Kamaishi, Iwate 026-0025, Japan.

J Thorac Cardiovasc Surg 2001;121:180-2

Copyright () 2001 by The American Association for Thoracic Surgery

$0022-5223 / 2001 \$ 35.00+0 \quad \mathbf{1 2 / 5 4 / 1 0 9 5 4 4}$

doi:10.1067/mtc.2001.109544 stenosis, was accomplished. Any outcome that did not accomplish the aims was judged unsatisfactory.

Patients. Between December 1996 and November 1999, 11 patients aged 48 to 87 years (mean 68.1 years) received the APC treatment. The patients included 7 men and 4 women, having 3 benign tumors, 3 metastatic tracheobronchial tumors, and 5 primary lung cancers. The aims of the procedure were curative resection in 3 patients, hemostasis and reduction of the tumor before endotracheal stenting in 5 patients, dilation of tracheobronchial stenosis in 5 patients requiring oxygen supplementation, and evaluation of the tumor in 4 patients.

Results. Satisfactory results were achieved in 10 of 11 patients $(91 \%)$. In all 3 patients with a benign tumor, the tumor was resected along with a large specimen for making a definite diagnosis, and no additional surgery was required. No recurrences have been observed during the follow-up period. In the 2 patients with tumor of the upper trachea (patients 4 and 5), successful hemostasis and reduction of the tumor were achieved promptly. An expandable metallic stent was later placed in the trachea in these 2 patients.

The stenotic site was successfully dilated in 3 of the 4 patients with malignant stenosis, and the patients' symptoms, such as dyspnea, stridor, cough, and bloody sputum, were relieved immediately after the operation. In the remaining patient (patient 8), the procedure was a failure because of tumor extension into the peripheral bronchi of the left lower lobe. In 1 patient (patient 9), the resected tumor specimen revealed small cell carcinoma. A lobectomy of the left lower lobe was performed later.

All 6 patients with endobronchial bleeding due to a protruding tumor had successful hemostasis. The procedures caused little smoke, so that it was seldom necessary to interrupt the operation. Percutaneous oxygen saturation, blood pressure, and electrocardiogram were not changed during the procedure. The operating time ranged from 21 to 55 minutes (mean 35 minutes). No complications, either related or unrelated to the procedure, occurred in any of the patients.

Discussion. Recently, various treatments have been reported for the management of bronchial tumors. ${ }^{1-5}$ All have specific advantages and disadvantages that make them individually suited for particular purposes. The Nd-YAG laser is one of the most useful treatments for tracheobronchial tumors. ${ }^{1}$ However, perforation and fatal hemorrhage have been reported as serious complications of the laser, even in skillful hands, because of unpredictable high-energy densities with the potential to destroy the integrity of the bronchial wall. ${ }^{1}$ In addition, the laser has considerably restricted mobility due to the necessity of meeting the safety regulations and the requirement of a cooling 
Volume 121, Number 1

Table I. Patients' characteristics and outcomes

\begin{tabular}{|c|c|c|c|c|c|c|c|c|}
\hline $\begin{array}{l}\text { Patient } \\
\text { (age, sex) }\end{array}$ & $\begin{array}{l}\text { Disease } \\
\text { (histology) }\end{array}$ & Site & $\begin{array}{l}\text { Signs and } \\
\text { symptoms }\end{array}$ & Stenosis & $\begin{array}{l}\text { Aim of } \\
\text { APC }\end{array}$ & Result & Complication & $\begin{array}{l}\text { Current } \\
\text { status }\end{array}$ \\
\hline $1(72, M)$ & $\begin{array}{l}\text { Bronchial tumor } \\
\text { (hamartoma) }\end{array}$ & MLB & Cough & $90 \%$ & $\begin{array}{l}\text { Evaluation of } \\
\text { tumor; curative } \\
\text { resection }\end{array}$ & Satisfactory & None & 5 mo, alive \\
\hline $2(68, F)$ & $\begin{array}{l}\text { Bronchial tumor } \\
\text { (leiomyoma) }\end{array}$ & MLB & Cough & $90 \%$ & $\begin{array}{l}\text { Evaluation of } \\
\text { tumor; curative } \\
\text { resection }\end{array}$ & Satisfactory & None & $16 \mathrm{mo}$, alive \\
\hline $3(71, \mathrm{M})$ & $\begin{array}{l}\text { Bronchial tumor } \\
\text { (leiomyoma) }\end{array}$ & LB6 & Cough & $90 \%$ & $\begin{array}{l}\text { Evaluation of } \\
\text { tumor; curative } \\
\text { resection }\end{array}$ & Satisfactory & None & 15 mo, alive \\
\hline $4(58, F)$ & $\begin{array}{l}\text { Thyroid cancer } \\
\text { (papillary } \\
\text { adenocarcinoma) }\end{array}$ & UT & $\begin{array}{l}\text { Bloody } \\
\text { sputum; } \\
\text { stridor }\end{array}$ & $85 \%$ & $\begin{array}{l}\text { Hemostasis; } \\
\text { reduction } \\
\text { of tumor }\end{array}$ & Satisfactory & None & 13 mo, alive \\
\hline $5(87, F)$ & $\begin{array}{l}\text { Thyroid cancer } \\
\text { (papillary } \\
\text { adenocarcinoma) }\end{array}$ & UT & $\begin{array}{l}\text { Bloody } \\
\text { sputum; } \\
\text { stridor }\end{array}$ & $90 \%$ & $\begin{array}{l}\text { Hemostasis; } \\
\text { reduction } \\
\text { of tumor }\end{array}$ & Satisfactory & None & 7 mo, alive \\
\hline $6(74, M)$ & $\begin{array}{l}\text { Lung cancer (squamous } \\
\text { cell carcinoma) }\end{array}$ & LMB & $\begin{array}{l}\text { Bloody } \\
\text { sputum; } \\
\text { stridor }\end{array}$ & $90 \%$ & $\begin{array}{l}\text { Hemostasis; } \\
\text { dilation } \\
\text { of stenosis }\end{array}$ & Satisfactory & None & $3 \mathrm{mo}$, dead \\
\hline $7(48, M)$ & $\begin{array}{l}\text { Lung cancer } \\
\qquad \text { (adenocarcinoma) }\end{array}$ & RMB & Dyspnea & $85 \%$ & $\begin{array}{c}\text { Dilation of } \\
\text { stenosis }\end{array}$ & Satisfactory & None & $2 \mathrm{mo}$, dead \\
\hline $8(78, M)$ & $\begin{array}{l}\text { Lung cancer (squamous } \\
\text { cell carcinoma) }\end{array}$ & LMB & Dyspnea & $85 \%$ & $\begin{array}{c}\text { Dilation of } \\
\text { stenosis }\end{array}$ & Unsatisfactory & None & $2 \mathrm{mo}$, dead \\
\hline $9(67, M)$ & $\begin{array}{l}\text { Lung cancer (small } \\
\text { cell carcinoma) }\end{array}$ & LB6 & $\begin{array}{l}\text { Bloody } \\
\text { sputum }\end{array}$ & $95 \%$ & $\begin{array}{l}\text { Evaluation of } \\
\text { tumor; } \\
\text { hemostasis }\end{array}$ & Satisfactory & None & $8 \mathrm{mo}$, alive \\
\hline $10(52, F)$ & $\begin{array}{l}\text { Metastatic tumor } \\
\text { (adenocarcinoma) }\end{array}$ & LMB & $\begin{array}{l}\text { Bloody } \\
\text { sputum }\end{array}$ & $100 \%$ & Hemostasis & Satisfactory & None & 7 mo, alive \\
\hline $11(74, \mathrm{M})$ & $\begin{array}{l}\text { Lung cancer (squamous } \\
\text { cell carcinoma) }\end{array}$ & RUB & $\begin{array}{l}\text { Bloody } \\
\text { sputum }\end{array}$ & $100 \%$ & Hemostasis & Satisfactory & None & $13 \mathrm{mo}$, dead \\
\hline
\end{tabular}

$A P C$, Argon plasma coagulation; $M L B$, middle lobe bronchus; $L B 6$, left B6 segmental bronchus; $U T$, upper trachea; $R M B$, right main bronchus; $L M B$, left main bronchus; $R U B$, right upper lobe bronchus.

water connection. The laser also causes smoke, which sometimes interrupts the procedure. Brachytherapy and cryosurgery take a long time to gain effective results. ${ }^{2,3}$ Endobronchial electrosurgery with the aid of a fiberoptic bronchoscope and a diathermic snare can be applied only to polypoid tumors. ${ }^{4}$

APC with a flexible bronchoscope caused little smoke and allowed good visual control of the coagulation procedure, so that it was seldom necessary to interrupt the procedure. In our small series of fiberoptic bronchoscopic APC applications, there were no complications related to the procedure. Grund, Storek, and Farin ${ }^{5}$ reported that in 102 patients receiving 189 applications in the gastrointestinal tract for different indications, no complications or side effects caused by the method itself occurred during the follow-up period. The reason for the reduced incidence of complications with APC when compared with the laser may be that the penetration depth in APC is constant and controllable, in contrast to the laser. ${ }^{5}$ However, the effect of APC on the tumor seems to equal the efficiency of the laser. ${ }^{5}$

Although the technique with a rigid bronchoscope is useful, the sites to be reached with the rigid bronchoscope are limited. The procedure with a fiberoptic bronchoscope can be applied to lesions located anywhere within the sight of the bronchoscope. Although little experience has been gained with APC in bronchoscopy, no major complications have been reported.

The use of general anesthesia in bronchoscopic treatment might be considered a disadvantage. However, the procedure allowed no motion of the patient and steady visualization of the airway and helped to avoid injuring the tracheobronchial wall during the operation. As a result, no risky complications were associated with the manipulation of the laser probe.

Although further study on a larger scale is required to establish the indications and limitations in the treatment of bronchial lesions with a flexible bronchoscope and APC, the technique described here may be effective and safe for the management of tracheobronchial tumors.

\section{REFERENCES}

1. Brutinet WM, Cortese DA, McDougall JC, Gillio RG, Bergstralh EJ. A two-year experience with the neodymium-YAG laser in endobronchial obstruction. Chest 1987;91:159-65.

2. Marasso A, Gallo E, Massaglia GM, Onoscuri M, Bernardi V. Cryosurgery in bronchoscopic treatment of tracheobronchial stenosis: indications, limits, personal experience. Chest 1993;103:472-4. 
3. Raben A, Mychalczak B. Brachytherapy for non-small cell lung cancer and selected neoplasms of the chest. Chest 1997; 112:276S-86S.

4. Gerasin VA, Shafirovsky BB. Endobronchial electrosurgery. Chest 1988;93:270-4.

5. Grund KE, Storek D, Farin G. Endoscopic argon plasma coagu- lation: first clinical experiences in flexible endoscopy. End Surg 1994;2:42-6

6. Birmingham B, Mentzer SJ, Body SC. Laryngeal mask airway for therapeutic fiberoptic bronchoscopic procedures. J Cardiothorac Vasc Anesth 1996;10:519-20. 